\title{
Pendampingan Ibu Hamil Dalam Self Care Nutrition Management (SNM) Dalam Upaya Pencegahan Risiko Stunting di Kecamatan Air Periukan Seluma
}

\author{
"Nur Elly ${ }^{1)}$, Asmawati ${ }^{2)}$, Kheli Fitria Annuril ${ }^{2)}$, Rahma Annisa ${ }^{3)}$, \\ Betty Yosephin Simanjuntak ${ }^{4)}$, Anang Wahyudi' ${ }^{5}$ \\ ${ }^{1,2,3)}$ Program Studi Sarjana Terapan Keperawatan dan Ners Jurusan Keperawatan serta \\ ${ }^{4,5)}$ Program Studi DIII-Gizi Poltekkes Kemenkes Bengkulu
}

Corresponden author: asmawatinadhyra@gmail.com

Received : 22-2-2021 Accepted : 29-3-2021

Published: 30-3-2021

DOI: https://doi.org/10.37012/jpkmht.v3i1.551

\begin{abstract}
ABSTRAK
Tujuan kegiatan ini adalah meningkatkan pengetahuan ibu hamil dan meningkatkan self care dalam manajemen nutrisi kehamilan untuk mencegah risiko stunting. Metode kegiatan ini dilakukan melalui kegiatan edukasi dan pendampingan. Ibu hamiil yang didampingi kader adalah ibu hamil mulai trimester dua kehamilan yang berjumlah sejumlah 11 orang. Proses pendampingan dilakukan selama 3 bulan. Pendampingan dilakukan one by one dengan kunjungan rumah, observasi serta monitoring melalui kartu pantau. Kegiatan yang dilakukan selama pendampingan kader adalah melakukan edukasi terkait nutrisi kehamilan, melakukan pemeriksaan tanda-tanda anemia, menimbang BB setiap minggu, monitor konsumsi tablet tambah darah (TTD) dan mencatat dalam kartu monitoring. Hasil kegiatan ini berhasil meningkatkan pengetahuan dan perilaku self care manajemen nutrisi kehamilan. Dari 11 orang ibu hamil, $82 \%$ mengalami peningkatan berat badan, $91 \%$ kenaikan berat badan sesuai standar Institute of Medicine (IOM), $91 \%$ ibu hamil mengkonsumsi tablet tambah darah (TTD) setiap hari. Untuk konsumsi protein hewani, buah dan susu masih rendah. Diharapkan perlu perhatian berbagai pihak dalam meningkatan pengetahuan ibu dan pemberdayaan kader kesehatan dalam pencegahan risiko stunting.
\end{abstract}

Kata Kunci : ibu hamil, nutrition, self care, , stunting

\begin{abstract}
The aims of this activity to promote knowledge, of pregnant woman, promote self care in nutrition for prevent risk of stunting. Methodes of activity are education and accompaniment of pregnant woman. The women who involved in this are who had trimester II and III amount 11 peoples. The accompaniment progress on three month.The activity of accompaniment are pregnanvy nutritional of education, assessment of anemia sign, monitor body weight weekly and monitor consumption of ferrous tablet, and documented in monitoring card. The result of this, there were promoted knowledge of mother and self care behavior in nutrition. From 11 pregnant mother, $82 \%$ had body weight gain $91 \%$ had body weight gain suitable to Institute of Medicine (IOM) standards. $82.18 \%$ of pregnant women took Fe tablets every day but consumption of animal protein, fruit and milk is still low. It is hoped that the attention of steakholders to promote knowledgeof mother about prevention of stunting and accompaniment of cadres in risk of stunting prevention. Even though pregnant women have been provided with health information by midwives and given a KIA book which contains information about nutrition and how to maintain the health of pregnant women, it is not accompanied by structured educational efforts accompanied by assistance to improve the ability of mothers in pregnancy nutrition self-care management. Therefore the aim of this activity is to improve self-care nutrition management in pregnant women. The results of this educational activity have succeeded in increasing the knowledge and behaviour of self-care nutrition management for pregnant women to prevent the risk of stunting. Of the 11 pregnant women, $82 \%$ experienced weight gain, ,
\end{abstract}

Key Words : Pregnant Women, Self Care, Nutrition, Stunting 


\section{PENDAHULUAN}

Stunting merupakan salah satu masalah kesehatan terbesar pada anak di bawah umur lima tahun di dunia terutama di beberapa negara berpendapatan rendah sampai menengah dan penyumbang terbesar angka kesakitan dan kematian pada anak di bawah lima tahun (Rosmalina, Luciasari, Aditianti, \& Ernawati, 2018). Stunting adalah kondisi gagal tumbuh akibat kekurangan gizi kronis yang terjadi pada periode 1000 Hari Pertama Kehidupan (HPK) (De Onis et al., 2013) Penyebab stunting adalah kurangnya asupan nutrisi selama kehamilan, sanitasi yang kurang baik dan pola asuh yang tidak mendukung yang dapat mengakibatkan terganggunya perkembangan otak, metabolisme tubuh, dan pertumbuhan fisik (Aryastami \& Tarigan, 2017).

Data Riskesdas tahun 2018, secara nasional stunting pada anak balita sebanyak 30,18\%. Prevalensi stunting di Propinsi Bengkulu Prevalensi stunting di Propinsi Bengkulu pada tahun 2013 sebanyak 39,7\% dan tahun 2018 menurun menjadi 28\% (Kemenkes RI, 2018). Berdasarkan standar ambang batas menurut WHO, angka ini masih tinggi yaitu $<20 \%$ (WHO, 2014).

Dalam upaya penanggulangan stunting di Propinsi Bengkulu, oleh Kepala Badan Perencanaan Pembangunan Nasional RI untuk tahun 2020 telah ditetapkan daerah lokus stunting untuk Propinsi Bengkulu adalah Kabupaten Seluma dan Bengkulu Selatan. Dari 20 desa lokus stunting di Kabupaten Seluma, 2 (dua) desa diantaranya adalah Desa Talang Benuang dan Lokasi Baru Kecamatan Air Periukan yang merupakan wilayah kerja dari Puskesmas Dermayu. Jumlah balita yang mengalami stunting di Desa Talang Benuang sebanyak 19 orang dan di Desa Lokasi Baru sebanyak 14 orang.

Selain itu Angka kejadian anemia di Provinsi Bengkulu terus mengalami peningkatan setiap tahun. Berdasarkan data Dinas Kesehatan Provinsi Bengkulu tahun 2017, jumlah kejadian anemia secara absolut di Kabupaten/Kota sebanyak 4030 dari 40671 ibu hamil atau sebanyak 10\%. Kejadian anemia tertinggi berada di Kabupaten Seluma sebanyak 946 kasus, urutan kedua berada di Kota Bengkulu sebanyak 843 kasus dan ketiga berada di Kabupaten MukoMuko sebanyak 680 kasus (Dinkes Provinsi Bengkulu, 2018 ). Dampak anemia ini pada janin adalah pertumbuhan janin terhambat (PJT) yang merupakan risiko kejadian stunting di masa mendatang.

Dari hasil wawancara yang dilakukan oleh pengelola program KIA dan Gizi Puskesmas, layanan prenatal berupa intervensi spesifik belum optimal dilakukan. Kegiatan yang telah 
dilakukan berupa: 1) Pemberian Makanan Tambahan (PMT) pada semua ibu hamil dalam bentuk biscuit 1 dus/bulan namum tidak semua ibu hamil mau mengkonsumsinya dan ada laporan kepatuhan konsumsi PMT serta ketepatan sasaran konsumsi PMT dimaksud 2) Pemberian tablet tambah darah (TTD) (90 tablet) pada ibu hamil telah dilaksanakan, namun tidak semua ibu hamil mau mengkonsumsi sesuai anjuran dan tidak ada laporan kepatuhan konsumsi TTD 3) ANC dilaksanakan di puskesmas namun belum optimal dalam edukasi persiapan laktasi dan manajemen nutrisi ibu hamil 4) Sosialisasi stunting belum optimal dilakukan ke semua lapisan masyarakat terutama ibu hamil 5) Kasus anemia kehamilan tertinggi terjadi pada Kabupeten Seluma termasuk wilayah Kecamatan Air Periukan yang salah satu factor penyebabnya adalah masih rendahnya konsumsi TTD. Munculnya permasalahan ini dikarenakan kurangnya pengetahuan ibu hamil tentang nutrisi yang dibutuhkan selama kehamilan Solusi atas permasalahan yang ada pada mitra, program yang ditawarkan adalah bagaimana meningkatkan pengetahuan dan meningkatkan kesadaran serta perilakuk ibu dalam merawat kehamilannya secara mandiri (self care) terutama dalam manajemen nutrisi melalui program edukasi dan pendampingan ibu hamil yang dilakukan oleh kader. Tujuan dilakukan kegiatan ini adalah untuk meningkatkan self care nutrition management (SNM) ibu hamil untuk mencegah risiko stunting antara lain meningkatkan pengetahuan tentang stunting dan 1000 HPK, nutrisi kehamilan, meningkatkan perilaku self care nutition, meningkatkan pengetahuan dan konsumsi TTD dan terjadi kenaikan berat badan yang sesuai rekomendasi serta terdientifikasi risiko kejadian risiko pertumbuhan janin terhambat $(\mathrm{PJT})$.

\section{METODE PELAKSANAAN}

Tahapan kegiatan yang dilakukan untuk mengatasi masalah kesehatan yang ada adalah:

1. Persiapan

a. Advokasi dan konsolidasi ke Dinas Kesehatan Kab. Seluma, Dinas Pemberdayaan Perempuan dan Perlindungan Anak serta Dinas Pemberdayaan Masyarakat dan Daerah Kab. Seluma sebagai Langkah awal untuk mensinergikan kegiatan dengan program yang ada.

b. Persiapan dan pengembangan instrument meliput: instrument pre dan post test pengetahuan ibu hamil tentang nutrisi kehamilan, pengembangan kartu monitoring Fe dan BB, pengembangan kuisioner self care manajemen nutrisi ibu hamil,

c. Pembuatan buku pegangan untuk kader dan ibu hamil tentang nutrisi kehamilan 
d. Bersama kader kesehatan dalam mengidentifikasi data jumlah ibu hamil yang dilibatkan dalam proses kegiatan

2. Pelaksanaan

a. Sosialisasi tentang Stunting dan 1000 hari pertama kehidupan kepada masyarakat meliputi khalayak sasaran, kader, tokoh masyarakat dan steakholder di Desa Talang Benuang dan Lokasi Baru

b. Mengukur pengetahuan ibu hamil tentang stunting dan nutrisi kehamilan menggunakan kuesioner

c. Melakukan edukasi kesehatan dan nutrisi kehamilan pada kader selama 2 hari dan edukasi tentang nutrisi kehamilan pada ibu hamil selama 1 hari

d. Mengidentifikasi kader yang dapat mendapingi ibu hamil dalam manajemen nutrisi kehamilan selama 3 bulan

e. Kader melakukan pendampingan pada setiap ibu hamil antara lain;

1) Melakukan pendidikan kesehatan tentang stunting dan nutrisi kehamilan pada ibu hamil yang didampingi

2) Melakukan kunjungan rumah untuk memonitor konsumsi TTD setiap hari dan dicatat dalam kartu pantau

3) Monitoring BB ibu hamil setiap minggu dan mencatat dalam kartu monitoring BB dan kenaikan BB setiap minggu/bulan dan akhir bulan menyimpulkan apakah dalam batas normal atau abnormal

4) Melakukan pengawasan PMT ibu hamil KEK

5) Memonitor ibu hamil yang masuk risiko tinggi

f. Tim abdimas melakukan pemberian layanan kesehatan berupa

1) Pemeriksaan kesehatan berupa pemeriksaan antropometri

2) Pemeriksaan fisik ibu hamil : tanda-tanda anemia, antropometri (BB,TB,LILA), tanda vital untuk menilai tekanan darah dan lainnya

3) Pemeriksaan kehamilan untuk menilai tinggi fundus uteri untuk memprediksi berat badan janin, menilai denyut jantung dan letak janin

g. Kader melaporkan hasil kegiatan pemantauan nutrisi, konsumsi TTD dan kenaikan BB ibu hamil setiap bulan ke tim 


\section{HASIL DAN PEMBAHASAN}

Pelaksanaan kegiatan dilaksanakan selama 3 (tiga bulan) mulai bulan September hingga Nopember 2020. Selama kegiatan berlangsung, didukung oleh Dinas PPPAKB Kabupaten Seluma, Dinkes Seluma beserta jajarannya dan Kepala Desa Lokasi Baru dan Talang Benuang serta tokoh masyarakat setempat. Kegiatan yang dilakukan sesuai dengan tahapannya adalah sebagai berikut:

\section{Sosialisasi tentang Stunting dan 1000 HPK yang dilaksanakan tanggal 14} September 2020.

Peserta yang hadir dalam kegiatan ini sebanyak 55 orang yang terdiri dari kelompok sasaran ibu hamil trimester 2 dan 3 sebanyak 11 orang dan sisanya adalah dari unsur stakeholder terkait yaitu Kepala Dinas Kesehatan Seluma, Kepala bidan, Kepala seksi dan staf program KIA dan Kepala Desa Lokasi Baru dan Kades Talang Benuang, Bidan Desa, Kader berjumlah 30 orang, Pengurus PKK, Pengurus Posyandu Remaja, Tokoh Masyarakat dan Kader Pembangunan Manusia.

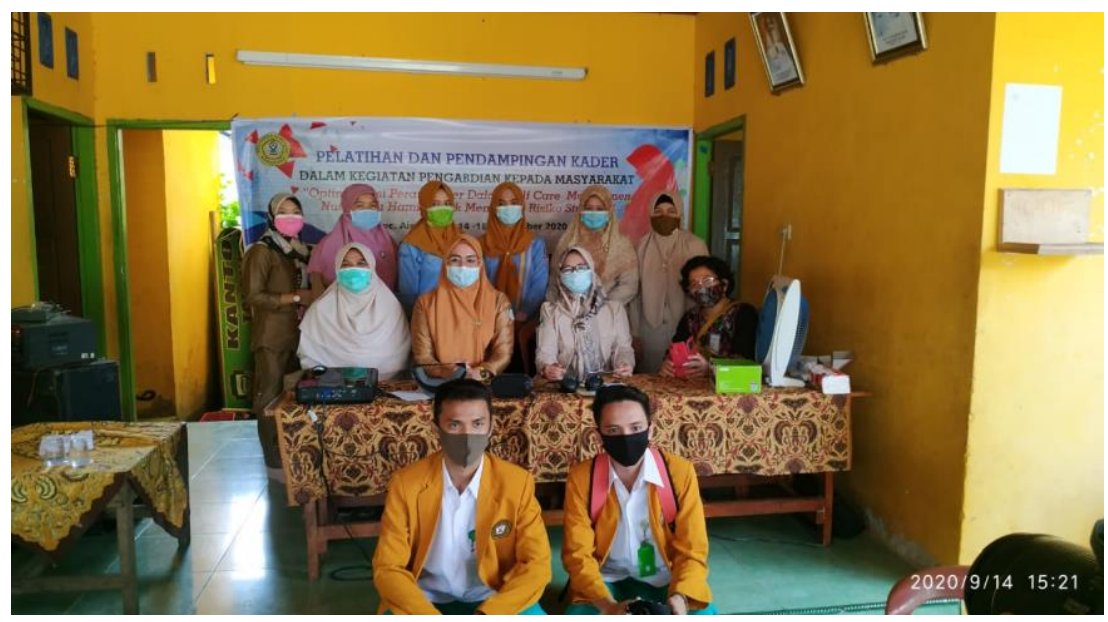

\section{Pelatihan Kader Kesehatan tentang Manajemen Nutrisi Kehamilan}

Sebelum kader disiapkan menjadi pendamping bagi ibu hamil, tim melakukan kegiatan pelatihan dan penyegaran kader kesehatan Puskesmas di Kabupaten Seluma terutama wilayah puskesmas Dermayu. Jumlah kader yang diiukutkan seluruhnya adalah 31 orang. Pelatihan dilaksanakan selama 2 hari yang dilaksanakan pada tanggal 14 September dan 21 September 2020 di Balai Desa Talang Benuang. Metode pelatihan secara luring dilakukan melalui ceramah/tatap muka dan tanya jawab, diskusi dan praktik dan diberikan buku pegangan kader. Pada kesempatan ini juga diberikan sosialisasi buku KIA baru. Setelah kader dilatih kader selanjutnya dapat melaksanakan tugasnya sebagai pendamping ibu hamil. 


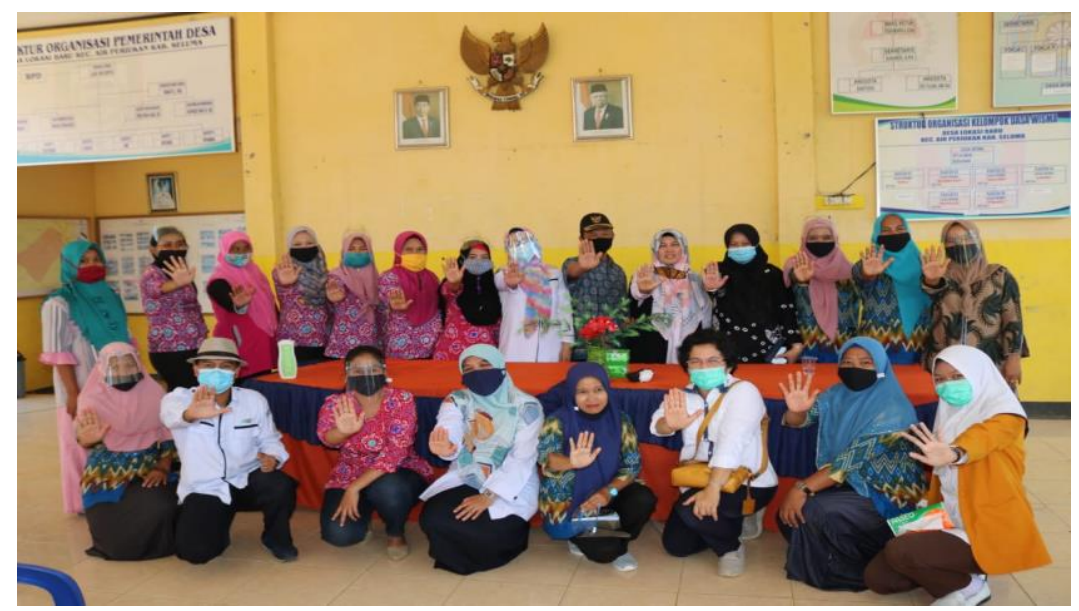

Gambar 1. Pelatihan Kader

\section{Edukasi tentang Kesehatan dan Nutrisi pada Ibu Hamil}

Materi yang diberikan adalah konsep stunting, nutrisi selama kehamilan, tanda bahaya kehamilan, persiapan laktasi dan ASI ekslusif, Inisiasi Menyusui Dini (IMD). Kegiatan ini dilakukan tanggal 5 Oktober 2020 dan dihadiri oleh 11 orang ibu hamil.

Setelah edukasi, dilakukan post test untuk mengetahui capaian perubahan tingkat pengetahuan ibu terhadap informasi yang diberikan.

Tabel 1.

Gambaran Pengetahuan ibu Pre dan Post Edukasi $(n=11)$

\begin{tabular}{lccc}
\hline \multicolumn{1}{c}{ Variabel } & Mean (SD) & Min-Max & P Value \\
\hline Pengetahuan & & & \\
Pre Edukasi & $47(9.5)$ & $25-70$ & 0.000 \\
Post Edukasi & $65(9.1)$ & $45-75$ & \\
\hline
\end{tabular}

Tabel 1 menggambarkan rata-rata pengetahuan ibu hamil sebelum edukasi adalah 47 dan terjadi perubahan rerata nilai pengetahuan menjadi 65 . Hasil uji statistic menunjukkan nilai p value 0.05 yang artinya ada perbedaan rerata pengetahuan ibu hamil setelah diberikan edukasi. Menurut Notoatmodjo (2012) pengetahuan merupakan hasil dari tahu dan ini terjadi setelah orang melakukan pengindraan terhadap suatu objek tertentu. Peningkatan pengetahuan ibu hamil terjadi setelah ibu mendapatkan informasi kesehatan yang dilakukan melalui pemberian materi melalui ceramah dan tatap muka secara langsung, tanya jawab, diskusi dan konsultasi yang diperlukan ibu selama kehamilan dari petugas kesehatan dan dosen. Kurangnya pengetahuan yang baik tentang kehamilan dapat menimbulkan berbagai konsekuensi bagi kesehatan ibu dan janin yang dikandung, misalnya asupan nutrisi yang kurang dan anemia selama kehamilan bisa menyebabkan stunting pada bayi. 

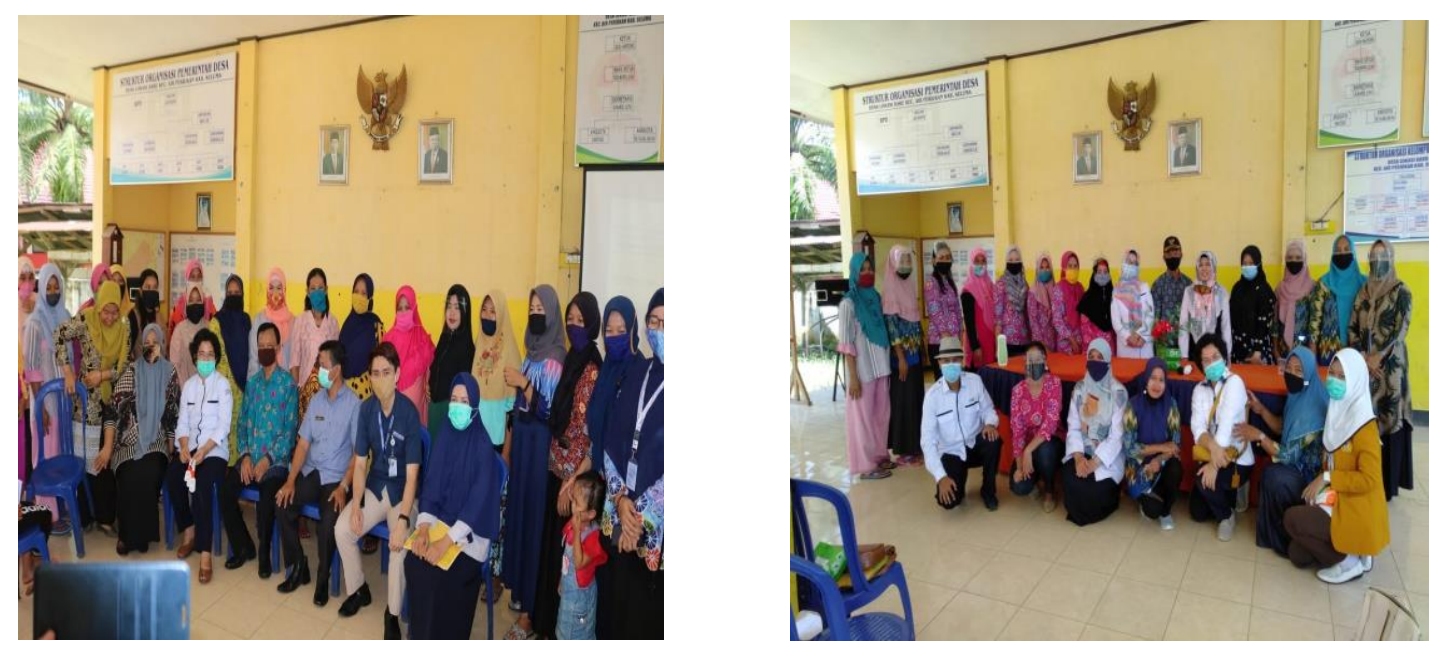

Gambar 2: Pelaksanaan sosialisasi Stunting di Balai Desa

\section{Pendampingan Ibu hamil oleh Kader Kesehatan}

Pada tahap ini, kader melakukan pendampingan untuk meningkatkan self care nutrition management agar kebutuhan nutrisi kehamilan terpenuhi melalui edukasi, kunjungan rumah, pemeriksaan fisik untuk menilai tanda anemia secara sederhana, menilai kenaikan BB dan memonitor kenaikan BB sesuai IMT dan mencatat dalam kartu pantau yang telah dibuat dan melaporkan hasil kegiatan melalui whatapps group dan secara langsung.

Kader yang dilibatkan dalam mendampingi adalah kader yang ada di dua lokasi yakni kader Desa Lokasi Baru dan kader Desa Talang Benuang yang berjumlah 11 orang. Ibu hamil yang didampingi ada 11 orang jadi rasio 1:1. Hasil kegiatan ini dapat dilihat pada tabel berikut.

Tabel 2.

Distribusi Kenaikan BB Ibu Hamil

\begin{tabular}{lcc}
\hline Berat Badan & Jumlah & Prosentase \\
\hline Meningkat & 9 & $82 \%$ \\
Tetap & 1 & $9 \%$ \\
Menurun & 1 & $9 \%$ \\
\hline Kenaikan Berat Badan & & \\
Melebihi Standar & 0 & $0 \%$ \\
Sesuai Standar & 10 & $91,0 \%$ \\
Kurang dari Standar & 1 & $9,0 \%$ \\
\end{tabular}

Dari tabel di atas menunjukkan bahwa $82 \%$ ibu hamil mengalami terjadi kenaikan BB namun masih ada 1 orang (9\%) yang mengalami penurunan BB. $91 \%$ ibu hamil mengalami kenaikan BB sesuai dengan standard IOM namun masih ada 1 (9\%) ibu hamil yang mengalami penurunan BB 


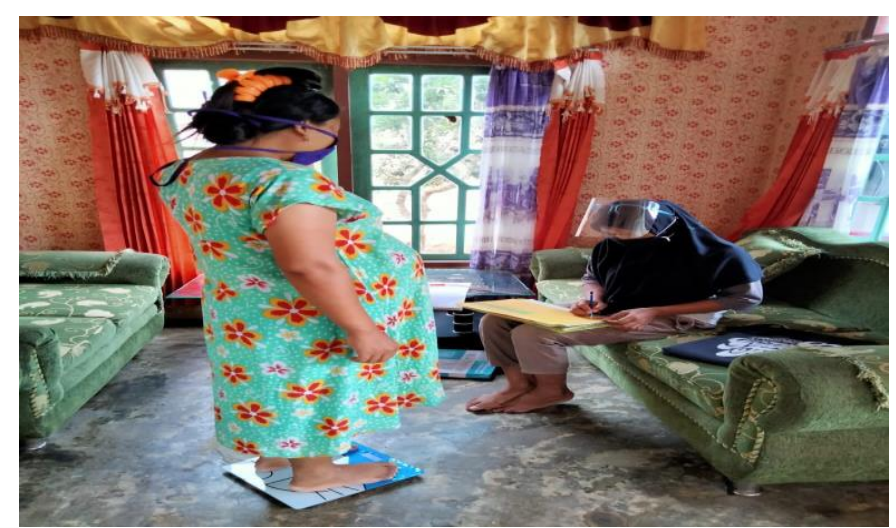

Gambar 3. Monitoring BB Ibu hamil

\section{Pemberian Makanan Tambahan (PMT) dan Monitoring Konsumsi Tablet Tambah Darah (TTD)}

Kegiatan ini dilakukan pada tanggal 15 Oktober 2021 yang bekerja sama dengan Puskesmas Dermayu. PMT diberikan oleh pihak Puskesmas dalam bentuk biscuit yang difokuskan pada ibu hamil dengan Kekurangan Energi Kronis (KEK). Selain itu juga dilakukan monitoring konsumsi TTD dan pemberian TTD yang dilakukan Puskesmas yang dapat dilihat pada tabel berikut :

Tabel 3.

Distribusi Konsumsi Tablet TTD selama kehamilan

\begin{tabular}{lcc}
\hline Konsumsi TTD & Jumlah & Prosentase \\
\hline Sebelum Pendampingan & 4 & \\
Kurang < 10 tablet & 5 & 36,4 \\
Cukup 10-20 tablet & 2 & 45,5 \\
Baik > 20-30 tablet & & 18,2 \\
\hline Setelah Pendampingan & 0 & \\
Kurang < 10 tablet & 3 & 18,18 \\
Cukup 10-20 tablet & 9 & 81,82 \\
Baik > 20-30 tablet & & \\
\hline
\end{tabular}

Dari tabel di atas menunjukkan bahwa $81.82 \%$ ibu hamil meminum tablet tambah darah sesuai dengan yang dianjurkan namun masih ada $18,18 \%$ ibu hamil yang belum meminum tablet tambah darah dengan alasan tidak mengalami anemia dan meminum selang hari. Hasil ini sesuai dengan penelitian Purnamasari, Margawati, \& Widjanarko (2016) bahwa kepatuhan ibu hamil dalam mengkonsumsi TTD adalah 60,4\% dan yang tidak patuh 39,6\%. Ketidakpatuhan meminum tablet tambah darah dipengaruhi oleh diri ibu sendiri yakni kesadaran akan pentingnya TTD bagi dirinya dan janin yang dikandungnya. Selain itu adalah pengetahuan ibu hamil tentang kegunaan tablet tambah darah, efek mual setelah mengkonsumsi dan dukungan keluarga. Pemberian kartu partau TTD dapat meningkatkan konsumsi TTD, yang dilaporkan dalam penelitian (Rumintang, 
Sundayani, \& Halimatusyaadiah, 2019) dengan menggunakan stiker kartu pantau terhadap kepatuhan konsumsi tablet Fe menunjukkan bahwa kelompok yang diberikan stiker kartu pantau lebih tinggi konsumsi TTD dibandingkan kelompok yang tidak diberikan kartu pantau.

\section{Kegiatan Pelayanan Kesehatan Ibu Hamil}

Pada kegiatan ini juga dilakukan kegiatan pemeriksaan kesehatan ibu hamil meliputi pemeriksaan kehamilan (antropometri, pemeriksaan kehamilan menggunakan Maneuver Leopold, penambahan $\mathrm{BB}$ ibu hamil dan prediksi BB janin). Hasil pemeriksaan pada table 2.

Tabel 4.

Hasil Layanan Pemeriksaan Kehamilan

\begin{tabular}{|c|c|c|c|c|c|c|c|}
\hline \multirow[t]{2}{*}{ No } & \multirow{2}{*}{$\begin{array}{c}\text { Usia } \\
\text { Hamil }\end{array}$} & \multicolumn{4}{|c|}{ Pemeriksaan Kesehatan } & \multirow{2}{*}{$\begin{array}{l}\text { Prediksi } \\
\text { BB }\end{array}$} & \multirow{2}{*}{ Interpratasi Hasil Pemeriksaan } \\
\hline & & TD & TFU & DJJ & BB & & \\
\hline 1 & $30 \mathrm{mg}$ & $130 / 118$ & 23 & 149 & 70 & $1860 \mathrm{gr}$ & $\begin{array}{l}\text { Kehamilan normal, taksiran BB kurang } \\
\text { Risiko Hipertensi kehamilan }\end{array}$ \\
\hline 2 & $36 \mathrm{mg}$ & $110 / 76$ & 30 & 139 & 69.2 & $2790 \mathrm{gr}$ & $\begin{array}{l}\text { Kehamilan normal, taksiran BB janin } \\
\text { normal }\end{array}$ \\
\hline 3 & $36 \mathrm{mg}$ & $134 / 72$ & 30 & 149 & 76.5 & $2790 \mathrm{gr}$ & $\begin{array}{l}\text { Kehamilan normal, taksiran BB janin } \\
\text { normal }\end{array}$ \\
\hline 4 & $28 \mathrm{mg}$ & $109 / 73$ & 27 & 149 & 79.5 & $2635 \mathrm{gr}$ & $\begin{array}{l}\text { Kehamilan normal, taksiran BB janin } \\
\text { normal }\end{array}$ \\
\hline 5 & $23 \mathrm{mg}$ & $101 / 69$ & 20 & 149 & 58 & $1395 \mathrm{gr}$ & $\begin{array}{l}\text { Kehamilan normal, taksiran BB janin } \\
\text { normal }\end{array}$ \\
\hline 6 & $31 \mathrm{mg}$ & $122 / 81$ & 27 & 131 & 66.8 & $2480 \mathrm{gr}$ & $\begin{array}{l}\text { Kehamilan normal, taksiran } \mathrm{BB} \text { janin } \\
\text { normal }\end{array}$ \\
\hline 7 & $38 \mathrm{mg}$ & $109 / 78$ & 25 & 151 & 61.1 & $2170 \mathrm{gr}$ & $\begin{array}{l}\text { Kehamilan normal, taksiran BB janin } \\
\text { kurang }\end{array}$ \\
\hline 8 & $39 \mathrm{mg}$ & $109 / 77$ & 33 & 139 & 64.9 & $3410 \mathrm{gr}$ & $\begin{array}{l}\text { Kehamilan normal, taksiran } \mathrm{BB} \text { janin } \\
\text { normal }\end{array}$ \\
\hline 9 & $29 \mathrm{mg}$ & $102 / 66$ & 26 & 130 & 68.1 & $2325 \mathrm{gr}$ & $\begin{array}{l}\text { Kehamilan normal, taksiran BB janin } \\
\text { normal }\end{array}$ \\
\hline 10 & $27 \mathrm{mg}$ & $125 / 76$ & 25 & 159 & 61.2 & $2170 \mathrm{gr}$ & $\begin{array}{l}\text { Kehamilan normal, taksiran BB janin } \\
\text { normal, DJJ cepat (tachikardi)/irreguler }\end{array}$ \\
\hline 11 & $34 \mathrm{mg}$ & $109 / 70$ & 31 & 151 & 60.6 & $3100 \mathrm{gr}$ & $\begin{array}{l}\text { Kehamilan normal, taksiran } \mathrm{BB} \text { janin } \\
\text { normal }\end{array}$ \\
\hline
\end{tabular}



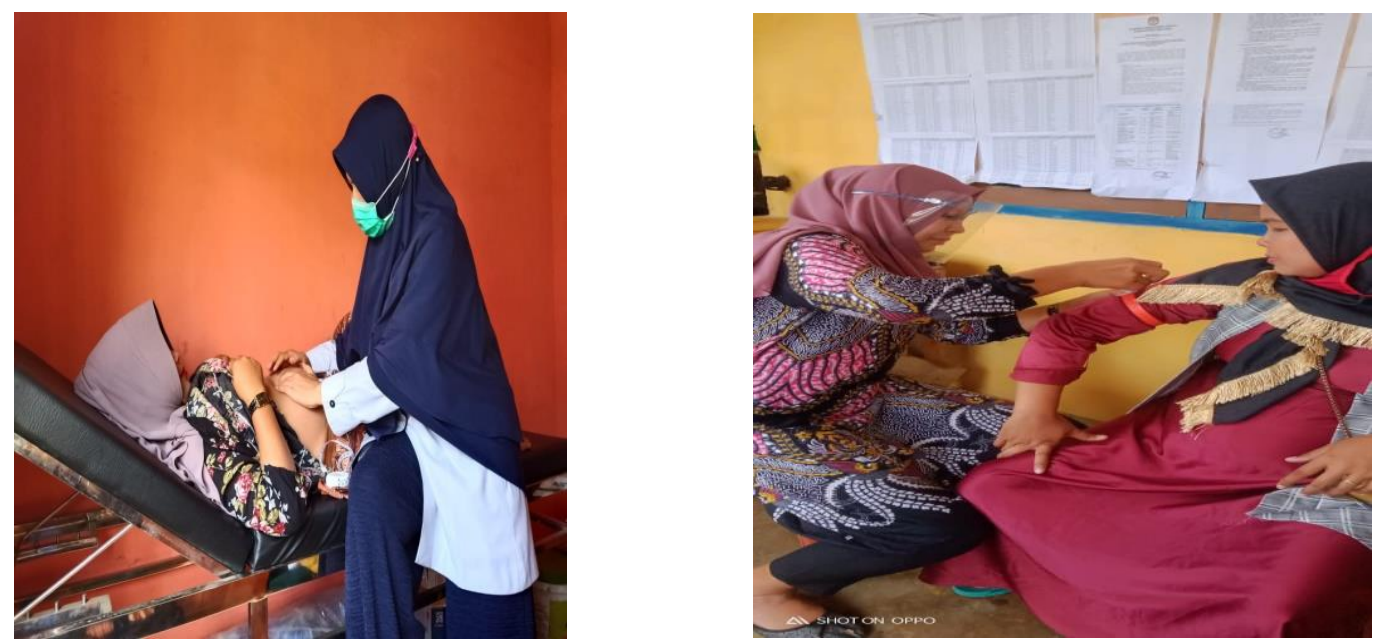

Gambar 3. Pemeriksaan kehamilan dan pengukuran LILA

\section{SIMPULAN}

Dari hasil kegiatan yang sudah dilakukan, didapatkan hasil bahwa ada peningkatan pengetahuan ibu hamil sebelum dan sesudah mengikuti kegiatan edukasi self care nutrition management dan pendampingan oleh kader; ada perubahan perilaku self care management nutrisi ibu hamil untuk mencegah stunting: $82 \%$ mengalami peningkatan berat badan, $91 \%$ kenaikan berat badan sesuai standar IOM, 81,12 \% ibu hamil mengkonsumsi tablet Fe setiap hari. Namun untuk konsumsi protein hewani, buah dan susu masih rendah.

\section{REFERENSI}

1. Aryastami, N. K., \& Tarigan, I. (2017). Kajian Kebijakan dan Penanggulangan Masalah Gizi Stunting di Indonesia. 45, 233-240.

2. De Onis, M., Dewey, K. G., Borghi, E., Onyango, A. W., Blössner, M., Daelmans, B., ... Branca, F. (2013). The world health organization's global target for reducing childhood stunting by 2025: Rationale and proposed actions. Maternal and Child Nutrition, 9(S2), 6-26. https://doi.org/10.1111/mcn.12075

3. Purnamasari, G., Margawati, A., \& Widjanarko, B. (2016). Pengaruh Faktor Pengetahuan dan Sikap Terhadap Kepatuhan Ibu Hamil dalam Mengkonsumsi Tablet Fe di Puskesmas Bogor Tengah. Jurnal Promosi Kesehatan Indonesia, 11(2), 100. https://doi.org/10.14710/jpki.11.2.100-115

4. Rosmalina, Y., Luciasari, E., Aditianti, A., \& Ernawati, F. (2018). Upaya Pencegahan Dan Penanggulangan Batita Stunting: Systematic Review. Gizi Indonesia, 41(1), 1. https://doi.org/10.36457/gizindo.v41i1.221 
5. Rumintang, B. I., Sundayani, L., \& Halimatusyaadiah, S. (2019). Penerapan model KIE dengan lembar balik dan stiker kartu pantau mandiri terhadap kepatuhan konsumsi tablet tambah darah (TTD) pada ibu hamil anemia di puskesmas wilayah kota mataram tahun 2016. 13(12), 1839-1846.

6. Dinkes Seluma. (2020). Profil Dinas Kesehatan Kabupaten Seluma Propinsi Bengkulu. Bengkulu: Dinkes Seluma.

7. Kemenkes RI. (2018). Riset Kesehatan Dasar (Riskesdas). Jakarta: Balitbang Kemenkes RI.

8. Kemenkes RI. (2018). Situasi Balita Pendek (Stunting) di Indonesia. Jakarta: Kemenkes RI.

9. Notoatmodjo, S. (2012). Promosi Kesehatan dan Ilmu Perilaku. Jakarta : Rineka Cipta.

10. WHO. (2018). World health statistics. Luxembourg: WHO. 